\title{
Extrahepatic manifestations of hepatitis B virus infection: Addison's disease and myelofibrosis in a patient with persistent hepatitis B surface antigenemia
}

\author{
FrançoIs SOMLO, MD, CSPQ, GERALD R BERRY, MD, FRCPC
}

\begin{abstract}
F SOMLO, GR BERRY. Extrahepatic manifestations of hepatitis B virus infection: Addison's disease and myelofibrosis in a patient with persistent HBsAg antigenemia. Can J Infect Dis 1993;4(3):139144. A 60-year-old white male patient was admitted to the hospital with acute abdominal pain, seemingly a self-limited ileus. He was found to be hepatitis B surface antigen (HBsAg)-positive. Previous dental treatment was suspected to be the initial source of the infection with hepatitis B virus. Five months later he was re-admitted with a diagnosis of adrenal insufficiency (Addison's disease) which responded well to steroids. Four years later he developed fever and leucocytosis. A bone marrow biopsy revealed myelofibrosis. He had several episodes of pyrexia during his lifetime. After a 12-year period the patient suffered a fatal myocardial infarction. At autopsy the adrenal glands were reduced to scarred remnants and HBsAg was found to be present in the residual adrenocortical cells by immunoflouresence methods. Bone marrow at autopsy revealed myelosclerosis as well HBsAg (via immunofluoresence). Hepatitis B virus was therefore closely correlated with the development of Addison's disease and myelofibrosis in this case.
\end{abstract}

Key Words: Addison's disease, Hepatitis B surface antigen, Hepatitis B virus, Myelofibrosis, Myelosclerosis

\section{Manifestations extrahépatiques du virus de l'hépatite B : maladie d'Addison ef myélofibrose chez un malade atteint d'antigénémie persistante}

RÉSUMÉ: Un mâle caucasien de 60 ans est hospitalisé souffrant de douleurs abdominales aiguës, dûes apparemment à un ileus. Il est HBsAg positif. Un traitement dentaire du passé pourrait être la cause de l'infection initiale au VHB. Cinq mois plus tard présentant une faiblesse générale il est hospitalisé de nouveau, la maladie d'Addison est alors diagnostiquée, elle sera par la suite traitée et bien contrôlée par les stéroïdes. Quatre ans plus tard il développe de la fièvre et une leucocytose. Une biopsie de la moëlle osseuse montre une myélofibrose. Il a ensuite plusieurs épisodes de pyrexies. A la fin de la $12^{\text {ième }}$ année de sa maladie, il subit un infarctus fatal. A l'autopsie les surrénales sont réduites à environ $1 \mathrm{~cm}, \mathrm{HBs} A g$ est détecté dans les cellules résiduelles par la méthode IF. La moëlle osseuse montre une myélosclérose et la présence de HBsAg par IF. On peut supposer une très proche corrélation entre la présence de l'antigène HBs et le développement de la maladie d'Addison et de la myélofibrose.

Department of Laboratories, Division of Microbiology, Department of Medicine, St Mary's Hospital Centre, Montreal, Quebec; and McGill University, Montreal, Quebec

Correspondence and reprints: Dr François Somlo, Microbiology \#G 200, St Mary's Hospital Centre, 3830 Lacombe Avenue, Montreal, Quebec H3T 1M5. Telephone (514) 345-3251 or 3262

Received for publication February 2, 1991. Accepted March 31, 1992 
$\mathrm{T}$ HE HUMAN HEPATITIS VIRUSES (A, B, C [NON-A, NON-B] AND Delta) may well replace syphilis in Osler's classical maxim "know syphilis and know disease", due to the extensive and variable nature of the non-hepatic clinical manifestations in patients with persistent hepatitis B surface antigenemia. In addition to acute hepatitis and hepatocellular carcinoma, many extrahepatic manifestations have been documented as being related to the hepatitis B virus infection $(1,2)$.

Hepatitis B is a $42 \mathrm{~nm}$, double-shelled DNA virus. Its surface coat bears a surface antigen, which circulates in the blood of infected individuals in addition to the intact virions, and outnumbers them by a factor of 100 to 1000. Hepatitis B surface antigen (HBsAg) may persist in the blood in enormous quantities, up to $10^{12}$ to $10^{14}$ particles $(3,4)$

Acute hepatitis B infection is characterized by a relatively long incubation period, malaise, nausea, vomiting, fever, right upper quadrant tenderness and jaundice. Manifestations may range from asymptomatic to rapidly fulminant disease. The majority of cases are self-limited, with further immunity conferred by the development of anti-HBs antibodies. A certain percentage of patients, however, go on to become chronic carriers, or have variable end-organ damage, both hepatic and extrahepatic (5-7). We report two new extrahepatic manifestations of chronic hepatitis $B$ antigenemia.

\section{CASE PRESENTATION}

A 60-year-old white male was admitted to St Mary's Hospital Centre in Montreal, Quebec in March 1978 because of acute abdominal pain, which subsided rapidly and was thought to represent a self-limited ileus. Hemoglobin was $16.2 \mathrm{~g} / \mathrm{dL}$ and white blood cell count was $18.2 \times 10^{9} / \mathrm{L}$ with $80 \%$ neutrophils, and platelets $543 \times 10^{9} / \mathrm{L}$. Bilirubin was $2.4 \mathrm{mg} / \mathrm{dL}$. The patient was found to be a carrier of HBsAg. There was no known past history of hepatitis. Previous dental treatment was suspected to be the initial source of the hepatitis $B$ virus (HBV) infection.

Five months later, the patient was readmitted because of slowly progressive severe generalized weakness. He had a brownish-grey discoloration on sun-exposed areas and in the palmar creases. Blood pressure was 70/40 mmHg. Adrenal insufficiency (Addison's disease) was confirmed with the appropriate tests. The patient responded well to treatment with corticosteroids. Hemoglobin was $11.4 \mathrm{~g} / \mathrm{dL}$, and white blood cell count was $9.6 \times 10^{9} / \mathrm{L}$. Antiadrenal antibody was reported to be negative; HBsAg remained positive. In 1982, he developed bouts of fever with a rising leukocytosis. In 1984, he was found to have newly diagnosed diabetes, as well as a complete blood count as follows: red blood cells, $13.8 \mathrm{~g} / \mathrm{dL}$; white blood cells, $16.6 \times 10^{9} / \mathrm{L}$; and platelets $348 \times 10^{9} / \mathrm{L}$. Ovalocytes, tear drops, and nucleated red blood cells were interpreted as a leuko-erythroblastic picture consistent with a diagnosis of myelofibrosis, confirmed with a bone marrow biopsy. The patient was treated with hydroxyurea and remained reasonably well until the fall of 1987, when he again developed severe weakness and dehydration. The spleen at this time was palpable. Hemoglobin was $10 \mathrm{~g} / \mathrm{dL}$ and white blood cell count was $30 \times 10^{9} / \mathrm{L}$. Splenectomy was performed.

The spleen weighed $2000 \mathrm{~g}$, and showed extramedullary hematopoiesis. Chromosome studies failed to reveal the presence of Philadelphia chromosomes or rearrangement of the $3^{\prime} \mathrm{BCR}$ focus.

The patient continued to have recurrent bouts of unexplained fever until his death on February 3, 1990 due to an acute myocardial infarction.

Autopsy confirmed myocardial infarction, liver disease, adrenal pathology and myelofibrosis. The liver weighed $2200 \mathrm{~g}$ and had signs of extramedullary hematopoiesis and pigmentary fibrosis. The adrenal glands were each only a few centimetres in size. The parenchymal cells were almost completely destroyed and replaced by loose fibro-areolar tissue. Cholesterolrich accumulation of necrotic debris with focal calcification was present. Mild inflammatory cell infiltration of the remnant of the gland and the periadrenal tissue was found along with some focal necrosis. Stains for mycobacteria and fungi were negative (Figure 1).

The bone marrow was replaced by fibrous tissue and increased cancellous bone with only focal remnants of hemopoietic components containing numerous ironladen macrophages and fibrosis (Figure 2).

\section{METHODS}

Routine paraffin sections of formalin fixed adrenals and Zenker fixed bone marrows from biopsies as well as from autopsy were placed on alcohol cleaned slides coated with glue (Lepage), and incubated in a ventilated dry air chamber at $56^{\circ} \mathrm{C}$ overnight. They were deparaffinized in xylene, rehydrated through graded ethanol and rinsed in calcium- and magnesium-free phosphate buffered saline. Treated sections were used in the following procedures:

- Tissues were explored using hematoxilin-eosin, Ziel-Nielsen and Gomory stains;

- Fluorescent antibody method was used for the search and localization of HBsAg.

\section{HBsAg localization, indirect method:}

1. Pepsin $(0.4 \%)$ was applied for $1 \mathrm{~h}$, followed by a wash in a calcium- and magnesium-free buffer.

2. Trypsin $(0.25 \%)$ in calcium chloride $(0.1 \%)$ was applied for 90 mins, followed by wash as above.

3. Hepatitis B human immunoglobulin (Hyper-Hep, Cutter Biological, California) was applied for 30 mins at $37^{\circ} \mathrm{C}$, followed by two washings.

4. Fluorescent-tagged anti-human immunoglobulin $\mathrm{G}$ was applied for $30 \mathrm{mins}$ at $37^{\circ} \mathrm{C}$, followed by two washings with the same buffer. 


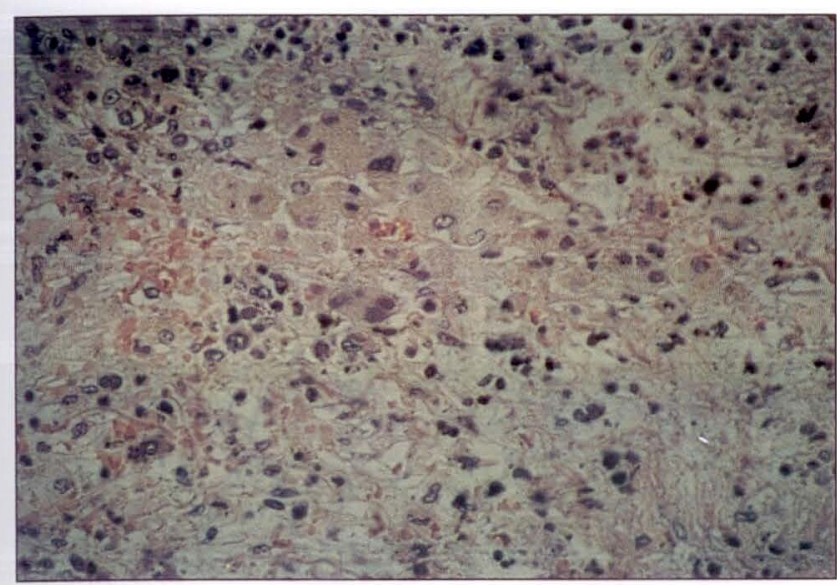

Figure 1) Hematoxylin-eosin staining of remnant of the adrenal gland with necrotic debris. Magnification $\times 264$

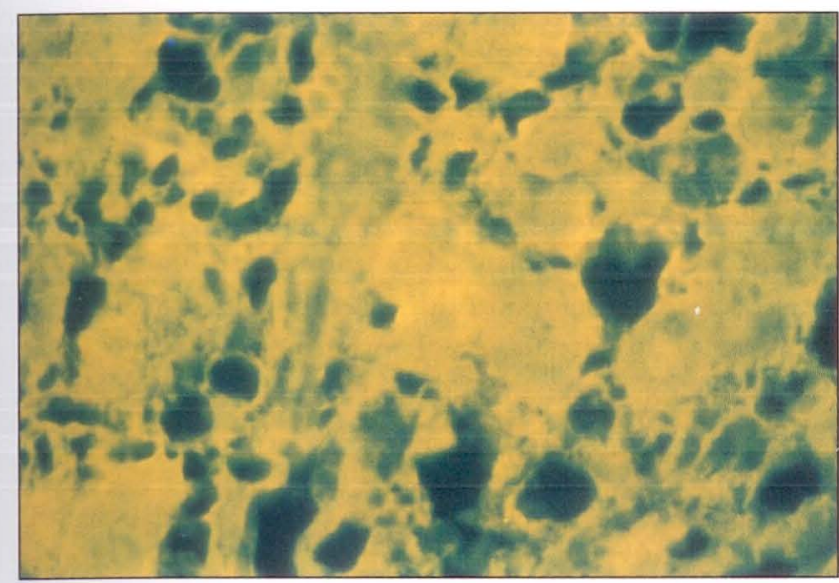

Figure 3) Indirect immunofluorescent staining showing hepatitis $B$ surface antigen in the remaining cells of the adrenal gland. Magnification $\times 264$

Negative controls: Replacement of hepatitis B human immunoglobulin: Slides were submitted to the same procedures, except for step 3, in which hepatitis B human immunoglobulin was replaced by phosphate buffered saline.

Absorption of hepatitis B human immunoglobulin: Hepatitis B human immunoglobulin was absorbed by incubating it at $40^{\circ} \mathrm{C}$ for $1 \mathrm{~h}$ with hepatitis $\mathrm{B}$ vaccine (Recombivax, Merck, Sharp \& Dohme, New Jersey). This mixture was applied to one slide as a negative control replacing hepatitis B human immunoglobulin in step 3. The hepatitis B human immunoglobulin attachment to the HBsAg in the cells could be eliminated in this control.

\section{RESULTS}

Positive immunofluorescent staining indicated the presence of HBsAg in the cells. Such staining was found in the remaining cells of the adrenal glands and the persisting hemopoietic cells fron the bone marrow (Figures 3,4$)$.

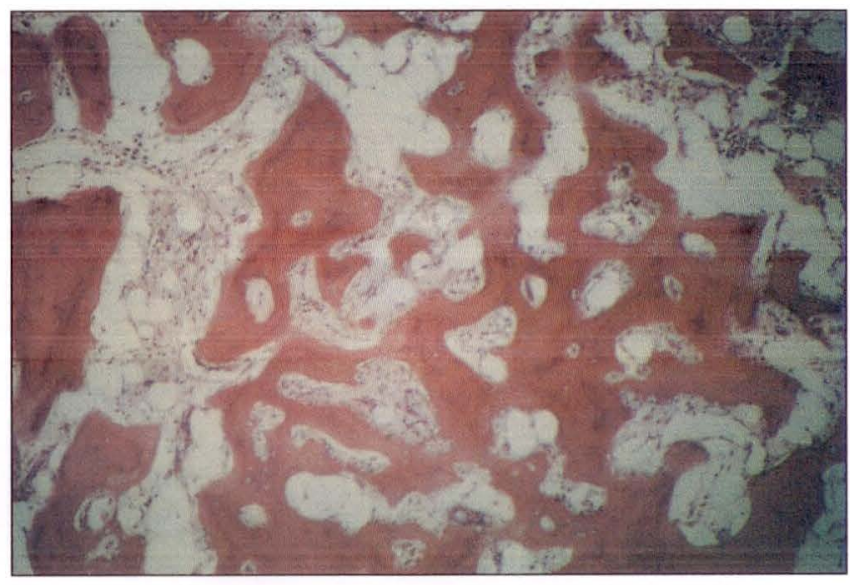

Figure 2) Hematoxylin-eosin staining of bone marrow showing replacement by fibrous tissue cancellous bone. Magnification $\times 264$

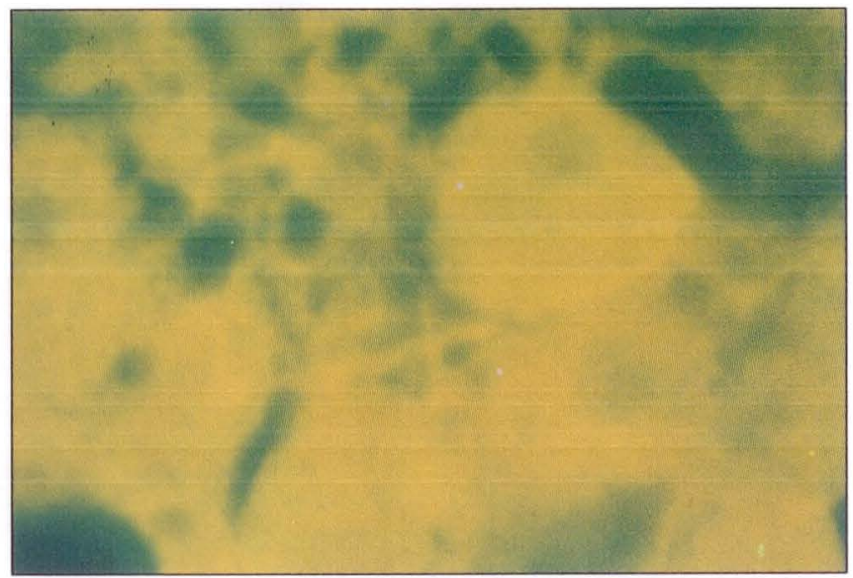

Figure 4) Indirect immunofluorescent staining showing hepatitis $B$ surface antigen in the cells of the remaining adrenal gland. Magnification $\times 528$

The control slides treated with antibody absorbed by hepatitis vaccine gave negative staining results. Those with phosphate-buffered saline instead of hepatitis B human immunoglobulin also gave negative staining results. Thus, immunofluorescent staining could only be elicited if both HBsAg and specific antibodies were present in the cells (Figures 5-10).

In addition, various pathological sections were stained with immunofluorescent antibody to search for the presence of HBsAg. Those organs were removed during the autopsy and the microscopic findings with hematoxylin and eosin stain were described earlier. No HBsAg was found in any of the sections from the heart, lungs, liver, pancreas, kidneys, thyroid gland or lymph nodes.

\section{DISCUSSION}

Current epidemiological surveys estimate approximately 300,000,000 individuals to be carriers of HBsAg worldwide, and some 40,000,000 deaths annually are attributed to chronic HBV infection. Six million of these deaths are due to hepatocellular carcinoma (11-13). 


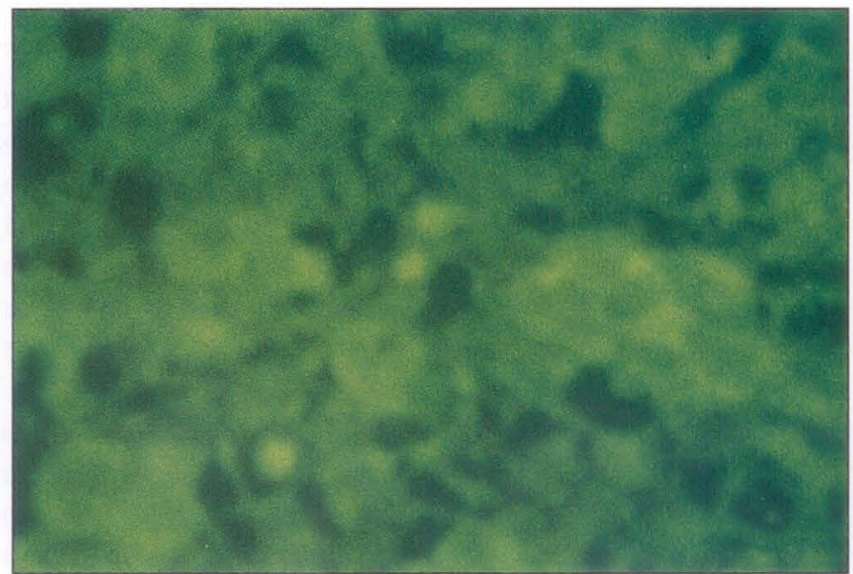

Figure 5) Absorption of hepatitis $B$ surface antibody, the hepatitis B human immunoglobulin, by hepatitis B vaccine (Recombivax; Merck Sharp \& Dohme, New Jersey). No antibody attachment seen in the cells of the adrenal gland. Magnification $\times 264$

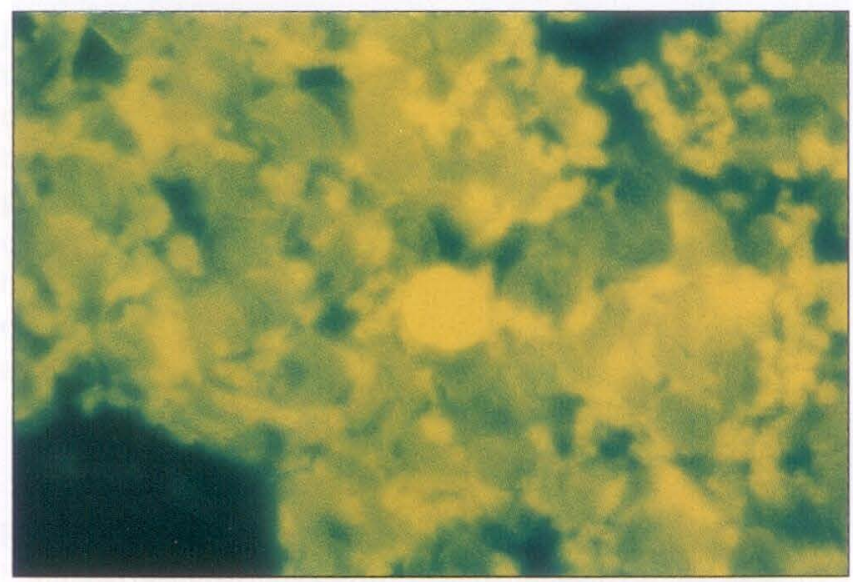

Figure 7) Indirect immunofluorescent staining of a bone marrow biopsy, showing attachment of hepatitis B surface antigen in the cells. Magnification $\times 264$

In adults, 5 to $10 \%$ of $\mathrm{HBV}$ infections lead to a chronic carrier state with persistent HBsAg positivity (14). In some parts of the world, HBV is frequently transmitted from infected mothers to babies at the time of birth or by intimate contact in infancy or early childhood, playing a major role in perpetuating the infection. In general, carriers who are positive with hepatitis B early antigen ( $\mathrm{HBeAg}$ ) are particulary infective. An infant born to an HBeAg-positive mother has a very high chance of being infected and of becoming a chronic carrier $(15,16)$.

The chronic carrier state has been demonstrated to be an important factor in the development of several serious diseases. Chronic active hepatitis, hepatic cirrhosis $(17,18)$, hepatacellular carcinoma (19), a variety of renal diseases $(20,21)$, arthritis $(22,23)$, essential mixed cryoglobulinemia (24), aplastic anemia (25), testicular carcinoma (26), and acrodermatitis (27) have all been associated with chronic HBsAg carriers.

It was originally believed that HBV flourished only in

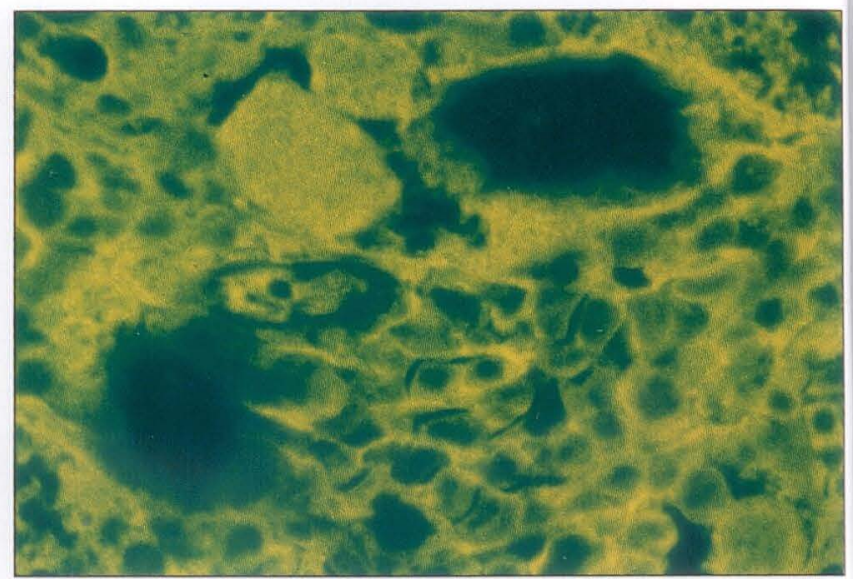

Figure 6) Indirect immunofluorescent staining of bone marrow biopsy from 1984, showing hepatitis B surface antigen in the cells. Magnification $\times 264$

the liver parenchymal tissue. The demonstration of HBsAg and HBV DNA in extrahepatic tissues (skin [28], pancreas and biliary secretion [29], leukocytes [30] and mononuclear cells [31]) has raised doubts about the so-called restricted tissue tropism of this virus.

The present patient, with known HBsAg-positivity for 12 years, developed Addison's disease and a myeloproliferative disorder, which progressed over six years from myelofibrosis of the marrow to myelosclerosis. Immunofluorescent staining showed the adrenal cortical cells and the persisting hemopoietic cells to contain HBsAg. These findings suggest that the pathological changes occurring in these organs were related to the persistent HBV viremia with seeding of the virus into the cells of those tissues. Addison's disease in this case was of the primary insufficiency type, caused by the destruction of the functioning adrenal cortical tissue. The adrenal glands are known to be affected during the course of a variety of acute viral infections: varicella (32), herpes simplex $(33,34)$, cytomegalovirus (35), Coxsackie virus (36) and rabies (37).

Recent studies of patients dying of acquired immunodeficiency virus infection have demonstrated destruction of the adrenal glands by cytomegalovirus (38-40). Several publications have appeared in the world literature reporting Addison's disease in families, but none of them has documented an associated viral infection, except one which reported Addison's disease in two brothers, with serum hepatitis in one (41).

The exact etiology of myelofibrosis remains unknown. It has been documented to have developed following exposure to toxins, ionizing radiation and chemotherapeutic agents, as well as occurring secondary to metastases to the bone marrow $(42,43)$. Two theories have been advanced to explain the pathogenesis of myelofibrosis: that there is primary damage to hemopoietic cells with secondary marrow fibrosis; and the reverse, that the primary event is in the connective 


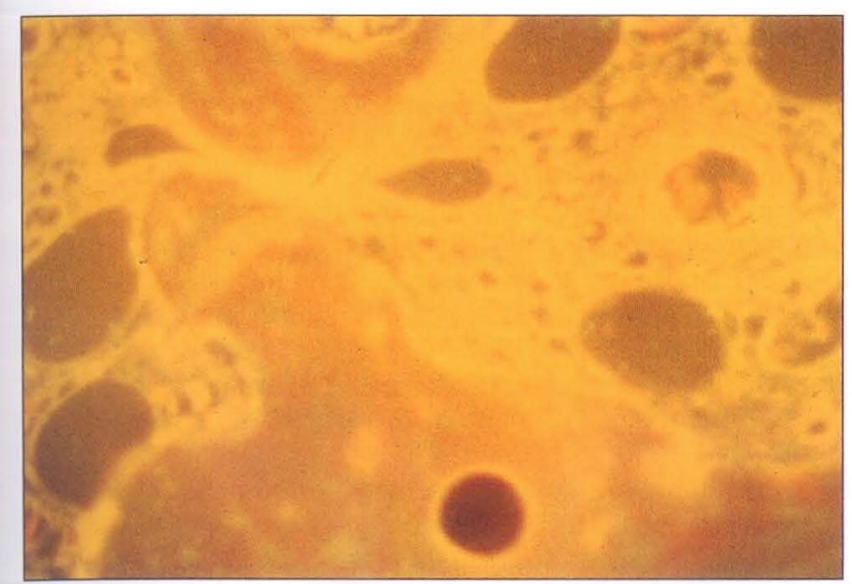

Figure 8) Absorption of the hepatitis B human immunoglobulin by hepatitis $B$ vaccine (Recombivax) no antibody attachment seen in the cells of the bone marrow. Magnification $\times 264$

tissue, resulting in a secondary effect on the hemopoietic cells $(44,45)$.

We know of no previous demonstration of any virus related to myelofibrosis in humans, however, transmissible murine virus has been demonstrated to induce myelofibrosis in mice after a long latent period. Neoplastic transformation of fibroblastoid marrow cells have been shown to result from infection of mouse marrow culture by a myeloproliferative sarcoma virus (46).

The mechanisms of the various extrahepatic manifestations of HBV are unknown. In the case of the present patient, there appears to have been necrosis and replacement of the adrenal cortical tissue, but whether this was due to direct viral damage or to an autoimmune reaction, in spite of an early negative report on antiadrenal antibody, remains unanswered. In the case of the myelofibrosis, the presence of HBV in the hemopoietic cells may also lead one to entertain a causative link between infection and pathogenesis of the disease.

\section{CONCLUSION}

The occurrence of these unusual manifestations raises the possibility that diseases occurring in association with persistent HBV infection may be the result of end-organ damage directly or indirectly caused by HBV.

Possible treatment with antiviral agents such as interferon-alpha might be tried in an effort to arrest the

\section{REFERENCES}

1. Gocke DJ. Extrahepatic manifestations of viral hepatitis. Am J Med Sci 1975;270:49-52.

2. Beasley RP, Hwang LY, Lin CC, Chien CS. Hepatocellular carcinoma and hepatitis B virus: A prospective study of 22,707 men in Taiwan. Lancet 1981;ii:1129-33.

3. Kim CY, Tilles JG. Purification and biophysical characterization of hepatitis B antigen. J Clin Invest 1973;52:1176-86.

4. Dreesman GR, Hollinger FB, Suriano JR, et al.

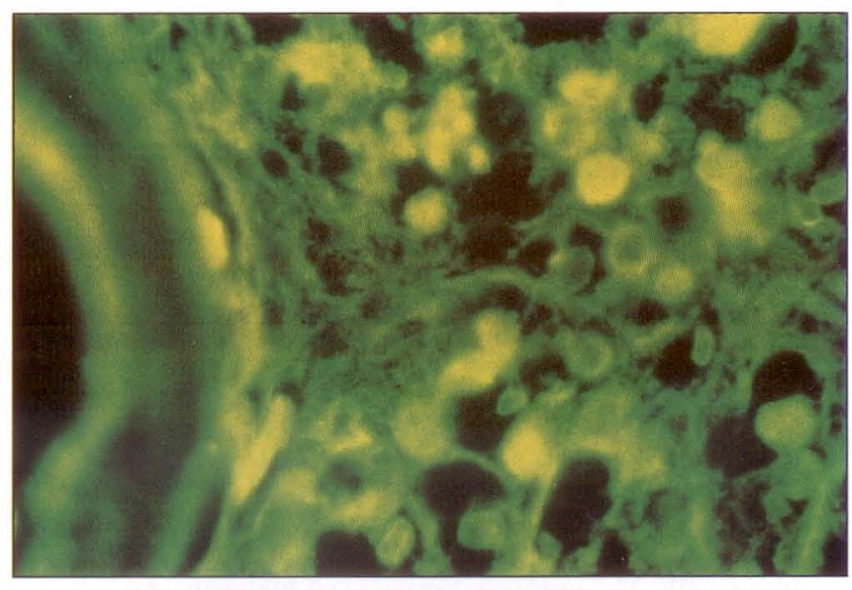

Figure 9) Indirect immunofluorescent staining of the bone marrow. Antibody attachment seen in the cells of the bone marrow taken during autopsy. Magnification $\times 264$

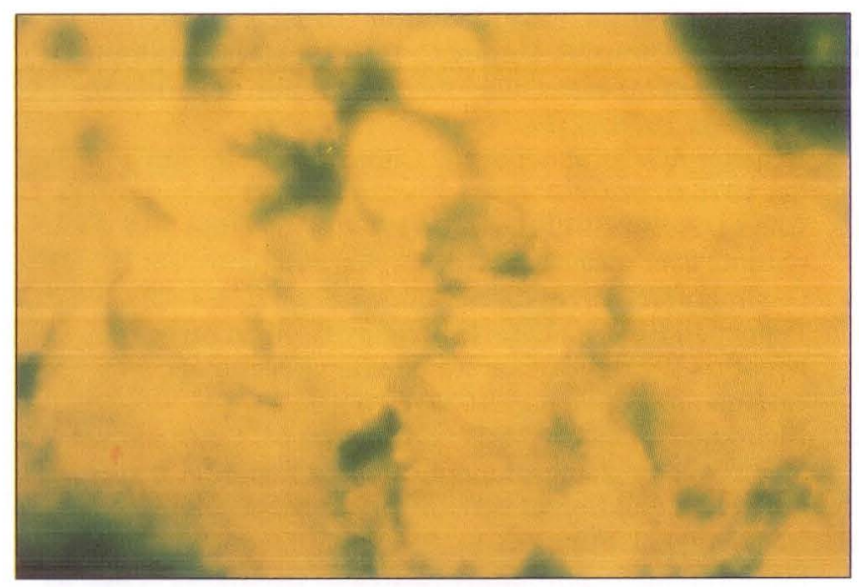

Figure 10) Indirect immunofluorescent staining of the bone marrow antibody attachment seen in the cells of the bone marrow taken during autopsy. Magnification $\times 528$

progress. Good clinical studies are needed to develop better treatment modalities. Prevention of the disease by more widespread immunization nust be emphasized.

ACKNOWLEDGEMENTS: The authors gratefully thank David S Kahn, MD, FRCPC, who was always available for consultation and suggestions on the manuscript. Special thanks to Catherine A Lounsbury, BSc, MD, for her help in editing this report. Many thanks to Claudette Dionne, ART, for excellent technical assistance.

Biophysical and biochemical heterogeneity of purified hepatitis B antigen. J Virol 1972;10:469-76.

5. Perrillo RP, Aach RD. The clinical course and chronic sequelae of hepatitis B virus infection. Semin Liver Dis 1981;1:5-25.

6. Redeker AG. Viral hepatitis: Clinical aspects. Am J Med Sci 1975;270:9-16.

7. McMahon BJ, Alberts SR, Wainwright RB, Bulkow L, Lanier AP. Hepatitis B-related sequelae. Prospective study in 1400 hepatitis B surface antigen-positive Alaska native 
carriers. Arch Intern Med 1990;150:1051-4.

8. Huang SN, Minassian H, More JD. Application of immunofluorescent staining on paraffin sections improved by trypsin digestion. Lab Invest 1976;35:383-90.

9. Dorsett BH, Ioachim HL. A method for the use of immunofluorescence on paraffin-embedded tissues. Am J Clin Pathol 1978;69:66-72.

10. Reid F, Hall NH, Smith JS, Baer G. Incresed imnunofluorescent staining of rabies-infected formalin-fixed brain tissue after pepsin and trypsin digestion. J Clin Microbiol 1983;18:968-71.

11. Maynard JE. Hepatitis B: Global importance and need for control. Vaccine 1990;8 (Suppl):S18-23.

12. London WT, Blumberg BS. Comments on the role of epidemiology in the investigation of hepatitis B virus. Epidemiol Rev 1985; 7:59.

13. Mosley JW. The epidemiology of viral hepatitis: An overview. Am J Med Sci 1975;270:253-70.

14. Trepo C. Viral hepatitis. Immune mechanisms. Am J Med Sci 1975;270:247.

15. Schweitzer IL. Infection of neonates and infants with hepatitis B virus. Prog Med Virol 1975;20:27-48.

16. Dupuy J, Girard P, Dupuy C. Hepatitis B in children. Analysis of 80 cases of acute and chronic hepatitis B. J Pediatr 1978;92:17.

17. Redeker AG. Viral hepatitis. Clinical aspects. Am J Med Sci 1975;270:9.

18. Chen DS, Sung JL. Hepatitis B virus infection and chronic liver disease in Taiwan. Acta Hepato Gastroenterol 1978;25:423-30.

19. Popper H, Shafritz DA, Hoofnagle JH. Relation of the hepatitis B virus carrier state to hepatocellular carcinoma. Hepatology 1987;7:764.

20. Kleinknecht C, Levy M, Peix A, Broyer M, Courtecuisse V. Membranous glomerulonephritis and hepatitis B surface antigen in children. J Pediatr 1979;95:946-52.

21. Kar Neng Lai, Philip KT Lt, Siu Fai Lui, et al. Membranous nephropathy related to hepatitis B virus in adults. N Engl J Med 1991;324:1457-63.

22. Schumacher HR, Gall EP. Arthritis in acute hepatitis and chronic active hepatitis: Pathology of the synovial membrane with evidence for the presence of Australia antigen in synovial membranes. Am J Med 1974;57:655.

23. Wands JR, Mann EA, Isselbacher KJ. The pathogenesis of arthritis associated with acute hepatitis B surface antigen positive hepatitis. Complement activation and characterization of circulating immune complexes. $\mathrm{J}$ Clin Invest 1975;55:930.

24. Levo Y, Gorevic PD, Kassab HJ, Zucker-Franklin D, Franklin EC. Association between hepatitis B virus and essential mixed cryoglobulinemia. N Engl J Med 1977;296:1501-4.

25. Hagler L, Pastore RN, Bergin JJ. Aplastic anemia following viral hepatitis. Medicine 1975;54:139.

26. Somlo F. Localization of hepatitis B virus in a primary testicular cancer. Arch Pathol Lab Med 1989;113:1184-6.

27. Colombo M, Gerber MA, Vernace SJ, Gianotti F, Paronetto F. Immune response to hepatitis B virus in children with papular acrodermatitis. Gastroenterology 1977;73:1 103-6.

28. Weiss TD, Tsai CC, Baldassare AR, Zuckner J. Skin lesions in viral hepatitis. Am J Med 1978;64:269-73.

29. Hoefs JC, Renner IG, Ashcavai M, et al. Hepatitis B surface Ag in pancreatic and biliary secretion. Gastroenterology 1980;79:191-94.

30. Hoar DI, Bowen T, Metheson D, Poon MC. Hepatitis B virus DNA is enriched in polymorphonuclear leucocytes. Blood 1985;66:1251-3.

31. Lamelin JP, Trépo C. The hepatitis B virus and the peripheral blood mononuclear cells: A brief review. Hepat J 1990;10:120-4.

32. Cheatham WJ, Weller TH, Dolan TF, Dower JC. Varicella: Report of two fatal cases with necropsy, virus isolation and serologic studies. Am J Pathol 1956;32:1015-35.

33. Brain RT, Pugh RCB, Dudgeon JA. Adrenal necrosis in a generalized herpes simplex. Arch Dis Child 1957;32:120-26.

34. Joseph TJ, Vogt PJ. Disseminated herpes with hepatoadrenal necrosis in an adult. Am J Med 1974;56:735-9.

35. Fisher ER, Davis E. Cytomegalic inclusion disease in the adult. N Engl J Med 1958;258:1036-40.

36. Hosier DM, Newton WA. Serious coxsackie infection in infants and children: Myocarditis, meningoencephalitis, and hepatitis. Am J Dis Child 1958;96:251-67.

37. Johnson HN. Rabies virus. In: Horsfall FL, Tamm I, eds. Viral and Rickettsial Infections of Man, 4th edn. London: Pitman, 1965:386.

38. Tapper ML, Rotterdam HZ, Lerner CW, Al'khafaji K, Seitzman PA. Adrenal necrosis in the acquired immunodeficiency syndrome. Ann Intern Med 1984;100:239-41.

39. Glasgow BJ, Steinsapir BS, Anders K, Layfield LJ. Adrenal pathology in the acquired immune deficiency syndrome. Am J Clin Pathol 1985;84:594-7.

40. Klatt EC, Shibata D. Cytomegalovirus infection in the acquired immunodeficiency syndrome. Arch Pathol Lab Med 1988;112:540-4.

41. Smith TW, Higgins AR. Addison's disease in two brothers, with serum hepatitis in one. Military Surgeon 1952; March: 180-4.

42. Smith RE, Chelmowski MK, Szabo EJ. Myelofibrosis: A concise review of clinical and pathologic features and treatment. Am J Hematol 1988;29:174-80.

43. Hasselbalch H. Idiopathic myelofibrosis: A clinical study of 80 patients. Am J Hematol 1990;43:291-300.

44. Hughes FJ, McCulloch AG. Stimulation of the differentiation of osteogenic rat bone marrow stromal cells by osteoblast cultures.Lab Invest 1991;64:617-22.

45. Mori KJ, Smadja-Joffe F, Barre-Sinoussi F, et al. Myeloproliferative sarcorma virus stimulates pluripotent hematopoietic stem cells and provokes tumoral transformation of the hematopoietic microenvironment in vitro. Leuk Res 1983;7:77-86.

46. Soule HD, Albert S, Wolfe PL, Bond B. Spontaneous and viral-induced myeloproliferative disorders in mice. U.S. Atomic Energy Symposium Series 1970;19:171. 


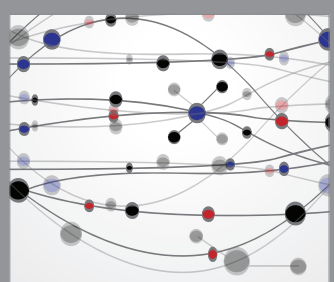

The Scientific World Journal
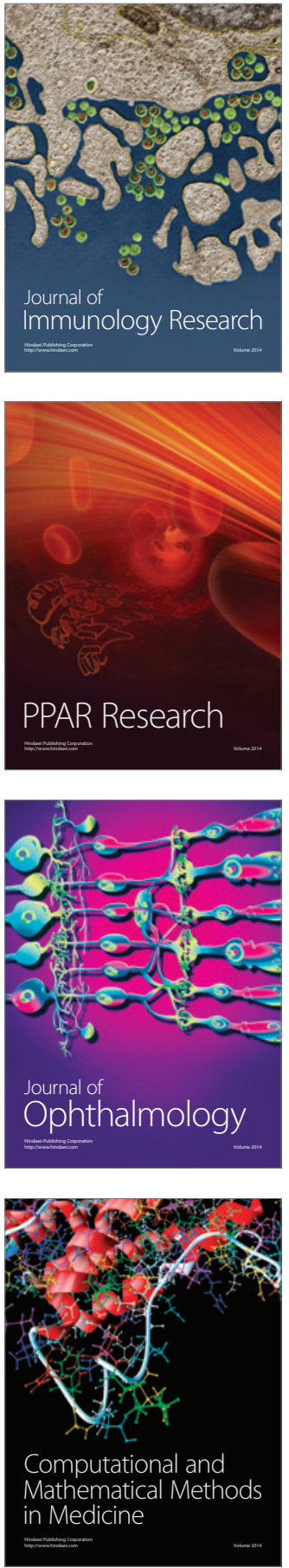

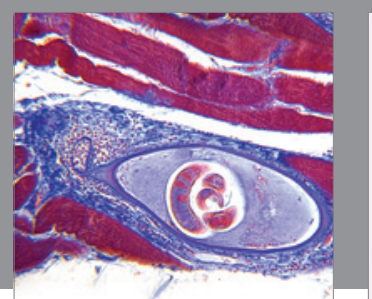

Gastroenterology Research and Practice

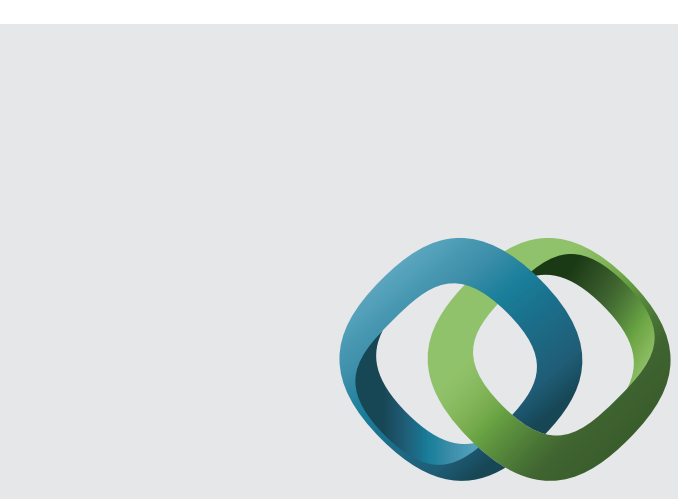

\section{Hindawi}

Submit your manuscripts at

http://www.hindawi.com
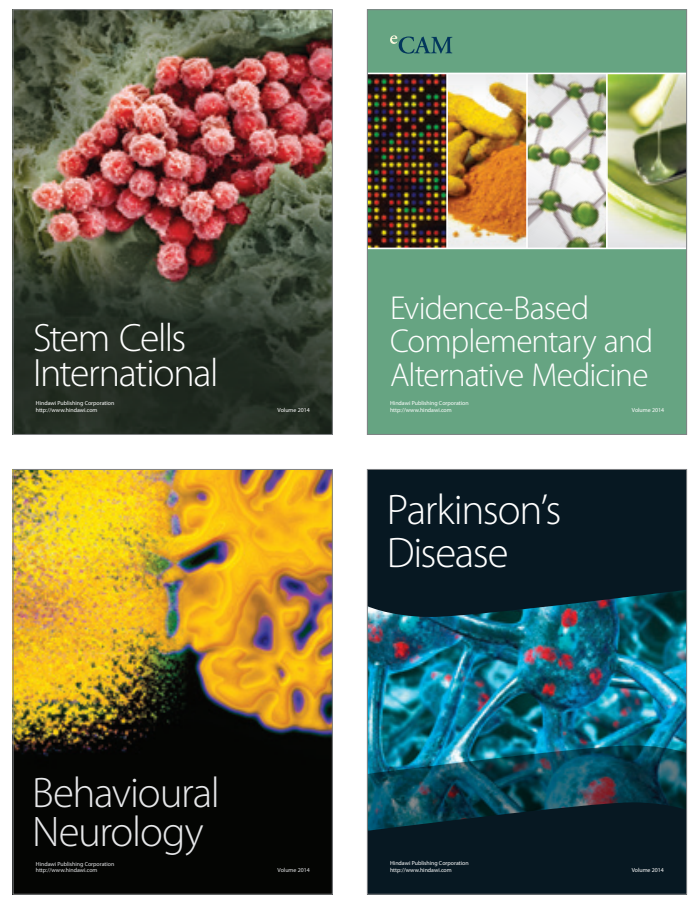
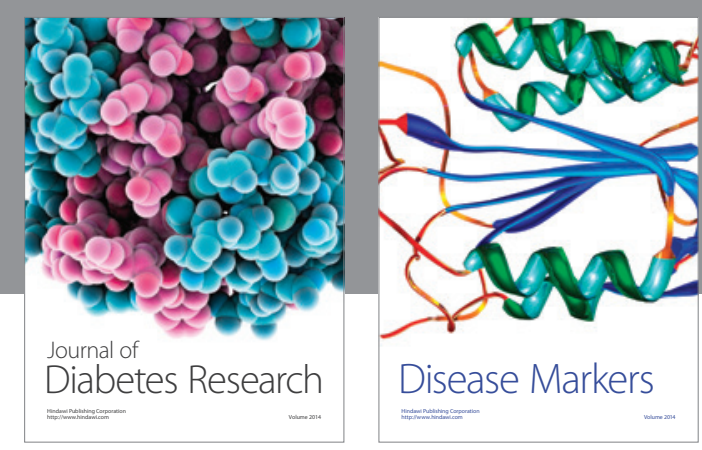

Disease Markers
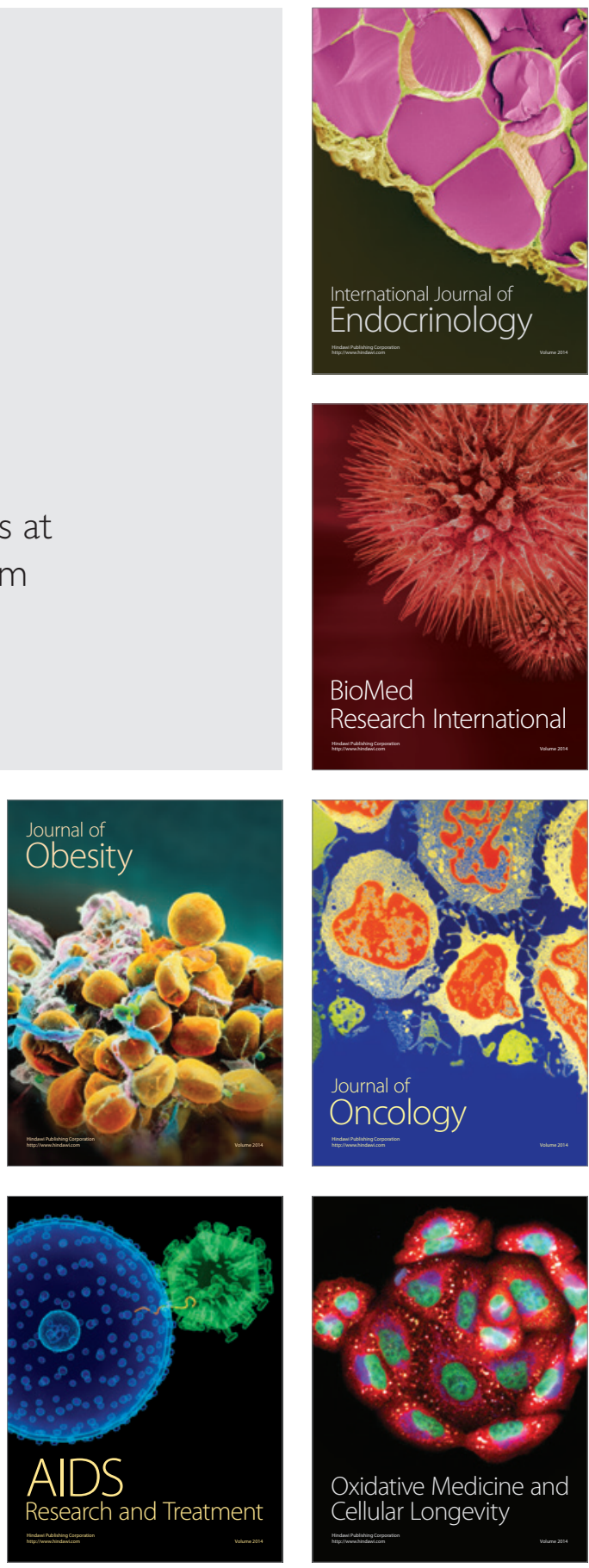